\title{
POVÁLEČNÉ STÁNKY POŠTOVNÍ NOVINOVÉ SLUŽBY
}

\section{STANDS OF THE POSTAL NEWSPAPER SERVICE OF THE POST-WAR PERIOD}

\author{
Mgr. BcA. Jana Bukačová ${ }^{1 *}$ \\ ${ }^{1}$ České vysoké učení technické v Praze, Fakulta architektury, Thákurova 9, 166 34, Praha 6 - Dejvice, Česká republika \\ *korespondenčni autor: jana.bukacova@fa.cvut.cz
}

\begin{abstract}
ABSTRAKT CZ
Text se věnuje jednomu z hlavních témat projektu „Drobná architektura ve veřejném prostoru v době poválečné (1945-1989)“ podpořeného grantem Studentské grantové soutěže ČVUT a zároveň je dílčím výstupem disertačního výzkumu autorky. Volně navazuje na článek publikovaný v tomto periodiku před dvěma lety (Poválečné telefonní budky, 02/2018). Zkoumaná problematika drobných úloh datovaných mezi roky 1945 až 1989 je zde představena na stánkách Poštovní novinové služby (dále PNS) objektech na pomezí architektury a designu, které byly produkované sériovou výrobou a navrhované pro celé naše území. Setkáváme se u nich s téměř mizivou produkcí originálně řešených projektů. Text ilustruje převažující typizovanou produkci, originálně řešené drobné stavby navrhované na konkrétní místa i tehdejší možnosti autorů v normalizační době.
\end{abstract}

Klíčová slova: Trafika, stánek Poštovní novinové služby, drobná architektura, veřejný prostor, poválečná architektura

\section{ABSTRACT}

Stands of the Postal Newspaper Service are one of the topics of the project ,Small Architecture in Public Space of the Post-War Period (1945-1989)“. The work was supported by the Grant Agency of the Czech Technical University in Prague. This article documents the origin and historical development of the stands (objects on the border between architecture and design) and describes their most important types in Czechoslovakia. Stands were objects produced by serial production and designed for the whole of our territory and examples document the possibilities of the normalisation era available to the architects.

Key words: Stands of the Postal Newspaper Service, small architecture, public space, architecture of the post-war period

\section{1 ÚVOD}

Drobné objekty s celonárodním charakterem, u kterých výrazně převažují typizované sériově vyráběné produkty nad individuálními realizacemi byly mezi lety 1945 až 1989 rozmístěné na celém našem území. Byla u nich žádoucí velká míra standardizace, která je oprávněná také u jiných typů drobné architektury jako jsou telefonní budky či zastávky a jejich př́stř̌šky. Mimo svou primární funkci tak přispívají ke sjednocení městských prostor a jednodušší orientaci obyvatel měst pomocí opakujících se bodů. Jednoduché mobilní obměny kamenných prodejen, sloužící k prodeji novin, časopisů, tabákových výrobků a upomínkových předmětů se instalovaly většinou tam, kde z různých důvodů nebylo možné zř́dit stabilní prodejnu a disponovaly obrovskou výhodou jednoduché a rychlé možnosti přemístění dle aktuální potřeby. Kromě typizovaných variant stánků Poštovní novinové služby, které dodávala 
Technická ústředna spojů, stály v ulicích velmi různorodé varianty kiosků či prodejních a informačních stánků, často kritizovaných pro svůj nejednotný vzhled i nevhodné umístění.

Některá zařizeni [...] nemaji specifický místní, ale celostátni charakter. Posiluje se tím jejich signální účinek usnadňující orientaci. Skutečnost, že nepřispivaji k posíleni specifičnosti sídla, nýbrž naopak ke společným rysům všech sídel ve státě, nelze hodnotit negativně (Procházka, Žižková 1981, s. 51-52).

\section{POČÁTKY STÁNKŮ PNS}

PNS začala stánky spravovat od první poloviny padesátých let. V té době nebyly nijak sjednocené, měly nedostatečnou půdorysnou plochu i skladovací prostory a jejich vstup se nacházel většinou v přední části, takže nezbýval dostatek místa na výkladní plochu. Proto začal velice záhy jejich správce $\mathrm{s}$ produkcí typizovaných objektů a $\mathrm{v}$ průběhu padesátých let za začaly vyrábět a průběžně instalovat celkem čtyři základní typy mobilních stánků. Šlo o jednoduché konstrukce z dřevotřískových desek $\mathrm{s}$ povrchovou úpravou $\mathrm{v}$ červenožluté barvě.

\section{TYPIZOVANÉ PROJEKTY}

\subsection{Sériově vyráběné stánky v 50 . až 70 . letech}

Od roku 1953, kdy Poštovní novinová služba převzala první stánky od různých soukromých provozovatelů, vznikalo průběžně několik jednoduchých typových variant, které se instalovaly do interiérů, často však bez ohledu na jejich vhodnost a souznění s okolním prostředím. Koncem šedesátých let se vyráběly čtyři varianty stánků: typ B2, D/T, Super D a nejnovější typ Služba. Nejvíce se užíval stánek Super D, který se jako první začal produkovat s pevně montovanou plechovou stř̌echou. Dřívější objekty se většinou instalovaly se stříškou z vlnitého plastu, jako základní materiál pro jejich výrobu se užívaly dřevotřískové desky a laminát. Od roku 1960 dodávaly stánky Jihomoravské dřevařské závody v Okř́̌škách, které mimo jiné vyráběly i telefonní kabiny. Nejprve se jednalo o prototypy zpracované podle návrhů architekta Višňáka, o dva roky později se začaly stánky vyrábět sériově (Anon. 1981, s. 14).

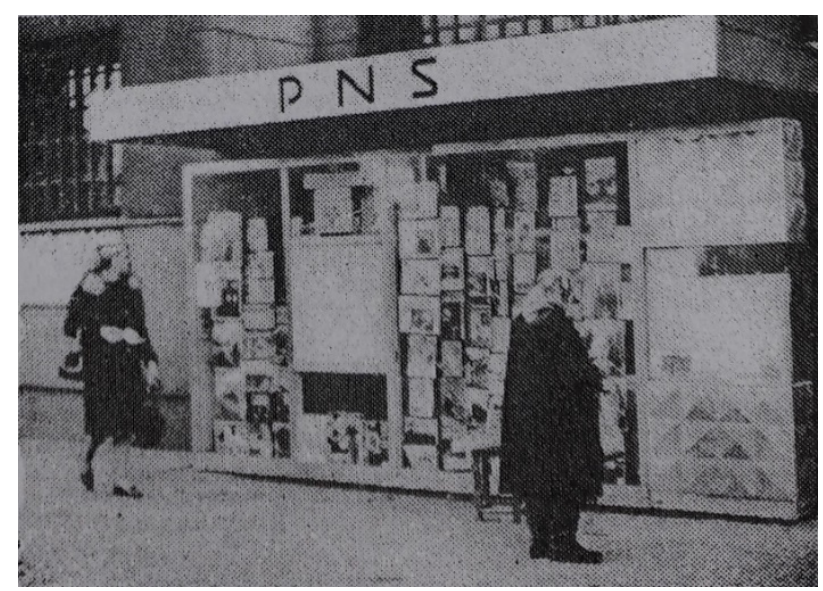

Obr. 1 Typizovaný stánek, šedesátá léta (Anon. 1965, s. 1)

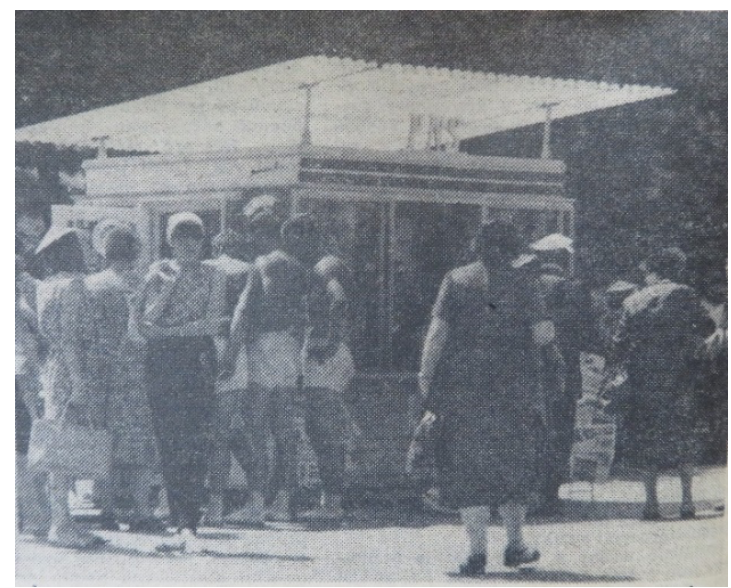

Obr. 2 Typizovaný stánek, šedesátá léta (Kubelík 1965, s. 6)

Hojně užívaný typ stánku Super D1, který disponoval největší skladovací i výložní plochou se poprvé objevil v Praze na Národní trrídě v polovině šedesátých let. Umístoval se většinou na chodníky v městské historické zástavbě. Krátce poté, před rokem 1970, prrišly do výroby stánky typu Super D2 a následně i Super D3. Jejich bezpečnost se řešila mřížemi v oknech a ocelovými pásy na dveřích. doi.org/10.51704/cice.2020.vol6.iss2.pp28-33 
Nerozbitné sklo náš trh tehdy nenabízel nebo výrobci neměly zájem o menší zakázky tohoto typu. Stejný problém představovala i kovová konstrukce (Bursík 68, s. 2), kterou se u nás na rozdíl od podobných zahraničních př́kladů nepodařilo tou dobou zajistit.

\subsection{Nový typ stánku v osmdesátých letech}

Spojprojekt Praha pobočka Brno navrhl roku 1987 nový typ prodejního stánku. Do té doby vyráběné objekty už nevyhovovaly požadavkům tepelně technickým, ergonomickým a požárním, ale také požadavkům na bezpečnost provozu nebo estetickým. Výrobní dokumentaci zpracovala Technická ústředna spojů Praha (Kokrdová 1987, s. 19), výrobcem stánku se staly stejně jako u předchozích typů Jihomoravské dřevařské závody v Okř́̌škách. Oproti ostatním tehdy používaným objektům zaručoval nový typ dobré tepelné vlastnosti a jeho velkou předností bylo elektrické vytápění, které umožňovalo komfortní celoroční provoz. Druhou zásadní změnou byla již dlouho diskutovaná celodřevěná

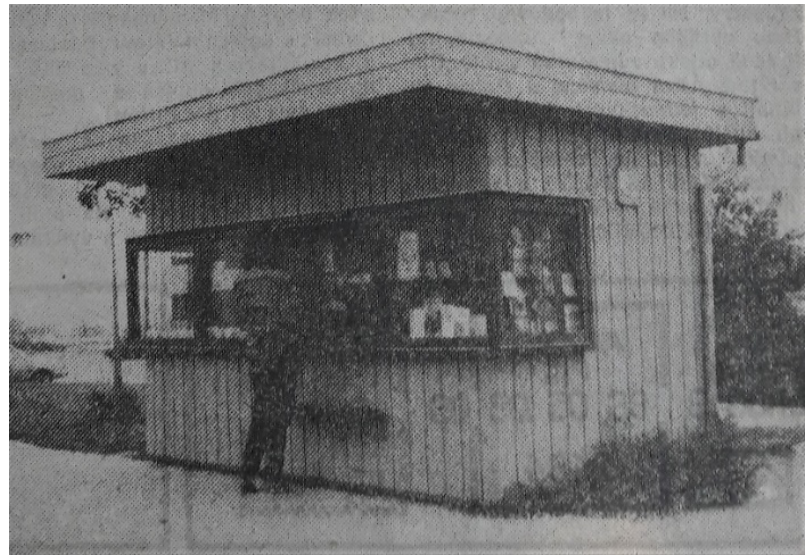

Obr. 3 Stánek Super D (Filla 1980, s. 155)

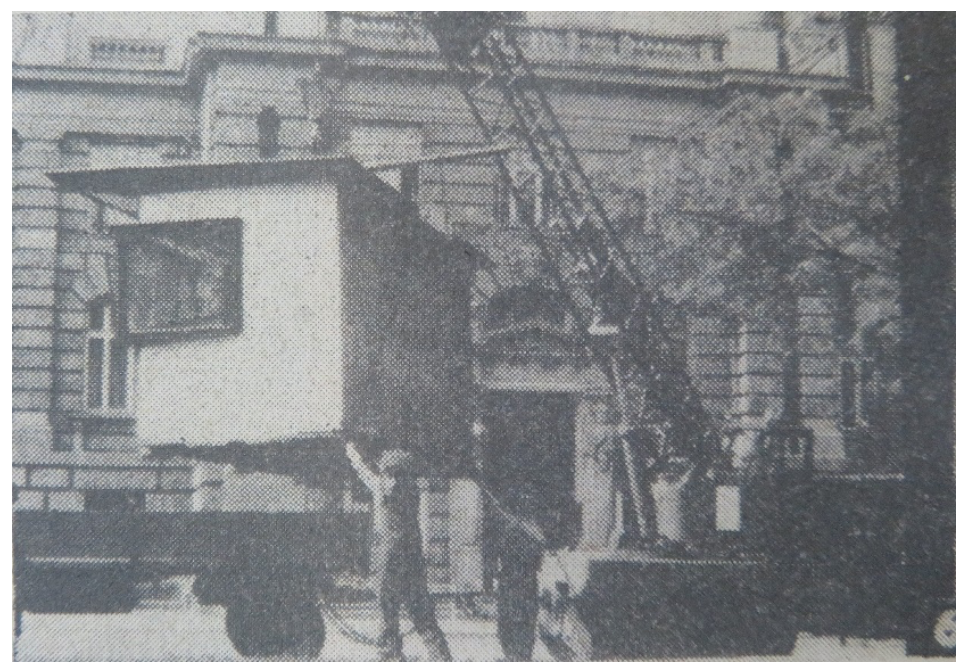

Obr. 4 Nový typ stánku Poštovní novinové služby z roku 1987 (Kokrdová 1987, s. 19)

konstrukce s venkovní úpravou $\mathrm{z}$ lisovaných dřevotř́skových profilů na povrchu laminované $\mathrm{v}$ dezénu př́rodního dubu. Okna stánku tvořilo dvouvrstvé lepené sklo, interiér výrobce vybavil typovými skříněmi na ukládání zboží, šatní skříní, čalouněnou otočnou židlí a zásobníkem na noviny a časopisy, který měl dviŕrka zvenčí i uvnitř. Po stranách prodejního okna se nacházely pulty určené k vystavení tiskovin, $\mathrm{k}$ další drobné výbavě patřil například elektrický radiátor s olejovou náplní a zářivkové 
osvětlení (Kokrdová 1987, s. 19). Pouze bezpečnost objektů nezaznamenala žádnou inovaci a zajištovaly ji stejně jako u předešlých typů dveřní i okenní mříže.

\section{ORIGINÁLNÍ PROJEKTY A REALIZACE}

V šedesátých letech plánovala Poštovní novinová služba zřídit ve všech pražských obvodech reprezentační prodejny. Tento záměr se nakonec neuskutečnil, ale souvisela s tím i snaha městské správy PNS o vybudování originálně řešených stánků určených na konkrétní místa v metropoli, odlišných od těch běžných typizovaných, které tou dobou již zaplnily ulice měst. Jedním z mála realizovaných projektů byl stánek u Parkhotelu v pražských Holešovicích postaveného mezi lety 1964 a 1967. Několik let po jeho dokončení vyrostl pod výškovou stavbou, př́mo u tramvajové zastávky v ulici Dukelských hrdinů atypický stánek, který byl dílem dvou z autorů projektového řešení samotného hotelu Zdeňka Edela a Jiřího Lavičky z Krajského projektového ústavu. Jeho elegantní řešení pracující hlavně se sklem a hliníkem se skládá z objektu autorsky řešeného stánku a samostatně stojící stř́íšky, která ho přesahovala a sloužila zároveň jako přístřešek pro čekající na tramvaj. Projekt byl řešen současně s návrhem hotelu již v roce 1966, nicméně téměř ihned po započetí stavebních prací byla stavba pozastavena, nejasná situace se vyřešila až po šesti letech a stánek se dočkal realizace dle původního autorského návrhu až roku 1972 (Rohár 1987, s. 110).
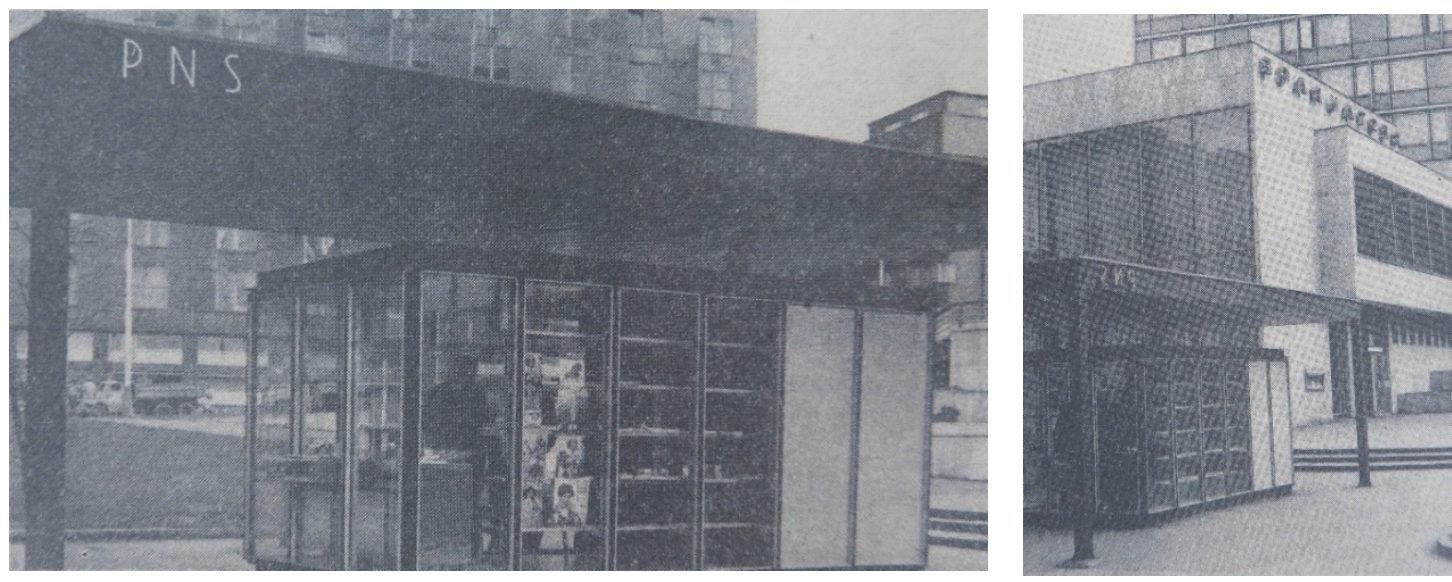

Obr. 5, 6 Atypický stánek pod pražských Parkhotelem, šedesátá léta (Anon. 1972, s. 12)

O dvacet let později oslovila Technická ústředna spojů Pavla Kosnáče, Vladimíra Bánského a Petera Havaše, autory úspěšného realizovaného návrhu typizovaných telefonních budek tou dobou zaváděných do výroby, s požadavkem na návrh nového typu stánku vycházejícího ze stejného modulárního principu. Autoři v roce 1984 navrhli několik alternativ laminátů různých půdorysů a rozměrů, v Čechách byl vyroben jeden prototyp, z neznámého důvodu se však nebyl nikdy realizován (Kosnáč, 18. 10. 2019). Stejně jako u telefonních budek počítal návrh s povrchovou úpravou v oranžové barvě kvůli dobré orientaci v městském interiéru, ale především proto, že jde o jednou z barev Československých spojů. Kvůli neuskutečněné realizaci stánků nedošlo $\mathrm{k}$ původně plánovanému tvarovému a barevnému sjednocení alespoň části typizovaného mobiliáře určeného pro celostátní užití. 

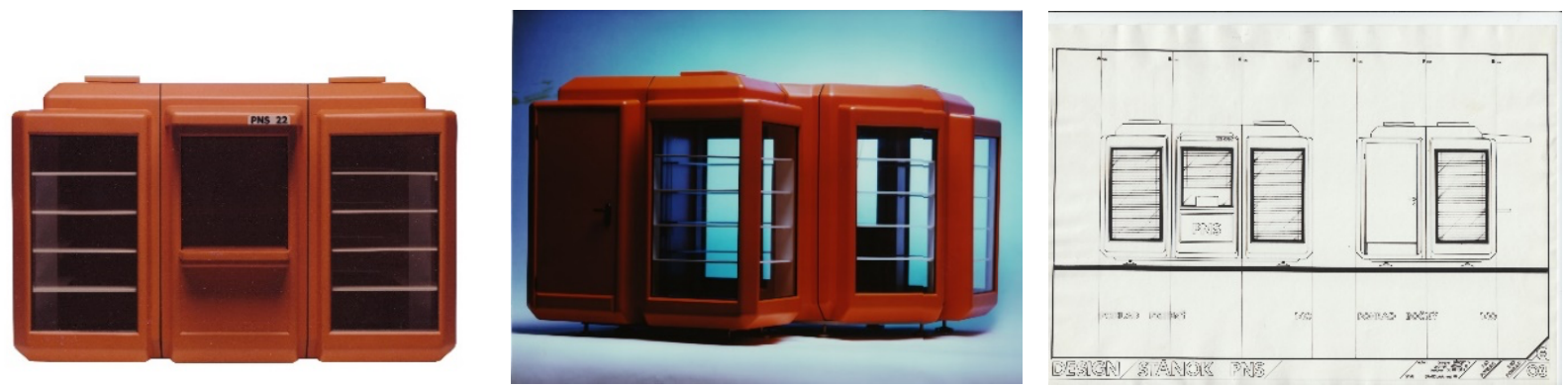

Obr. 7, 8, 9 Návrh modulových novinových stánků (Kosnáč, 18. 10. 2019)

Ojedinělá realizace se povedla v libereckém obchodním centru Ještěd (Karel Hubáček, Miroslav Masák, realizace 1968-1979), kde navrhl Michal Brix atypickou trafiku, v podobě krabičky od sirek konceptuální objekt stírající hranice mezi architekturou a výtvarným uměním. Obchodní dům byl však přes protesty roku 2009 zbourán.

\section{ZÁVĚR}

Od padesátých let, kdy začala mobilní stánky spravovat PNS se velmi rychle produkovaly a instalovaly základní čtyři typy sériově vyráběných objektů. Šlo o jednoduché konstrukce z dřevotř́skových desek $\mathrm{s}$ povrchovou úpravou v červenožluté barvě. $\mathrm{V}$ šedesátých letech $\mathrm{k}$ nim přibyl další inovovaný typ a ve druhé polovině osmdesátých let se začala vyrábět celodřevěná varianta, která do jisté míry nahradila předchozí tou dobou z mnoha důvodů nevyhovující typy. Od osmdesátých let často ze strany architektů i laické veřejnosti zazníval požadavek na větší množství estetičtějších i funkčnějších variant stánků, lépe se hodících do různorodých prostředí městských i vesnických interiérů. Po roce 1989 , kdy začali soukromí podnikatelé na sídlištích doplňovat již existující centra dalšími službami a rozvíjet samostatně stojící drobné architektury trafik, kiosků a stánků na exponovaných místech hlavních toků obyvatel. Požadavky provozovatelů však poháněla především potřeba rychlé instalace stánků bez ohledu na jejich estetické kvality.

\section{Poděkování}

Článek byl podpořen grantem Studentské grantové soutěže ČVUT č. SGS18/195/OHK1/3T/15 „Drobná architektura ve veřejném prostoru v době poválečné (1945-1989)“. 


\section{Použitá literatura}

[1] BUKAČOVÁ Jana. Mušle, velbloudi a létající talíře. In: Petr Vorlík, ed. (a)typ. Architektura osmdesátých let. Praha 2019.

[2] BUKAČOVÁ Jana. Za obytnější každodennost. Městský parter a drobné úkoly. In: Petr Vorlík, Klára Brůhová, eds. Nepostavená. Architektura osmdesátých let. Praha 2020.

[3] BAČÍK Martin. Viděli jsme ruch. Pošta PNS IV. 1966, č. 23.

[4] BURSÍK Marcel. Stánky PNS z druhé strany. Pošta PNS VI. 1968, č. 18, s. 2.

[5] GREGOR G. Bude už konečně vyřešena otázka vytápění novinových stánků? Pošta PNS VIII. 1970, č. 7.

[6] JANKOVÁ Yvonne. Kiosky. Domov. 1984, č. 3, s. 50-54.

[7] KOKRDOVÁ Ivana. Nový typ stánku pro Poštovní novinovou službu. Pošta PNS XXV. 1987, č. 2, s. 19.

[8] KOSNÁČ Pavel. Rozhovor autorky. Bratislava 18. 10. 2019.

[9] PROCHÁZKAVítězslav, ŽIŽKOVÁ Lenka. Urbanistický parter. Praha 1981.

[10] ROHÁR Pavol. Poštovní novinová služba. Prodejní sít' PNS v Třebíči. Pošta PNS XXV. 1987, č. 7-8, s. 110 .

[11] SEDLÁK Jaroslav. Občanská vybavenost, in: Rostislav Koryčánek, ed., Paneland. Největší československý experiment. Brno 2017.

[12] Anon. Jihomoravské dřevařské závody továrna na spojový nábytek v Okř́rškách. Pošta PNS XIX. 1981, č. 1, s. 14-15.

[13] Anon. Prostor, architektura, výtvarné umění. Ostrava, 1983 (katalog výstavy). Ostrava 1983.

[14] Anon. První vlaštovka. Další modernizace sítě PNS. Pošta PNS X. 1972, č. 4, s. 12-13. 